\title{
Plant and Soil Consequences of Shrub Management in a Big Sagebrush-Dominated Rangeland Ecosystem
}

\author{
Justin D. Derner ${ }^{1}$, Gerald E. Schuman ${ }^{1}$, Ronald F. Follett ${ }^{2} \&$ George F. Vance ${ }^{3}$ \\ ${ }^{1}$ USDA-Agricultural Research Service, Rangeland Resources Research Unit, USA \\ ${ }^{2}$ USDA-Agricultural Research Service, Soil, Plant and Nutrient Research Unit, USA \\ ${ }^{3}$ Department of Ecosystem Science and Management, University of Wyoming, USA \\ Correspondence: Justin D. Derner, USDA-Agricultural Research Service, Rangeland Resources Research Unit, \\ 8408 Hildreth Road, Cheyenne, WY 82009, USA. Tel: 1-307-772-2433. E-mail: Justin.Derner@ars.usda.gov
}

Received: October 21, 2013 Accepted: December 5, 2013 Online Published: December 20, 2013

doi:10.5539/enrr.v4n1p19 URL: http://dx.doi.org/10.5539/enrr.v4n1p19

\begin{abstract}
This study investigated plant and soil (organic carbon, SOC) responses to shrub management in western U.S. rangeland dominated by Wyoming big sagebrush (Artemisia tridentata Nutt. ssp. wyomingensis Beetle \& Young). Plants and soils were sampled in 2009 from paired sets of treatments (mowing to $10 \mathrm{~cm}$ height, aerial herbicide application of Spike ${ }^{\circledR}$ 20P [tebuthiuron]) in Sandy and Loamy ecological sites. Plant responses to mowing were consistent for both ecological sites with 1) no effects on live, but three- to four-fold increases in dead, Wyoming big sagebrush plant density, 2) reduced height and cover of Wyoming big sagebrush, 3) increased cover of perennial grasses, and 4) no effects on bare ground. For soils, increased SOC did occur with herbicide application in the Loamy site for both the $0-5 \mathrm{~cm}$ (43\% increase) and $5-15 \mathrm{~cm}(17 \%$ increase) soil depths, which corresponded to annual soil $\mathrm{C}$ sequestration rates of 0.16 and $0.14 \mathrm{Mg} \mathrm{Cha}^{-1} \mathrm{yr}^{-1}$ for the $0-5$ and $5-15 \mathrm{~cm}$ soil depths, respectively. Shrub management in Wyoming big sagebrush-dominated rangelands affects the plant component for two different ecological sites, whereas effects on SOC were observed only when density of live Wyoming big sagebrush plants was reduced through selective herbicide use.
\end{abstract}

Keywords: soil organic carbon (SOC), Wyoming big sagebrush, mowing, selective herbicide application, arid rangelands

\section{Introduction}

The world's rangelands represent a very large and diverse land resource, and encompass broad temperature and precipitation gradients. Rangelands have considerable potential to mitigate climate impacts resulting from rising atmospheric levels of various greenhouse gases (GHGs), such as carbon dioxide $\left(\mathrm{CO}_{2}\right)$, methane $\left(\mathrm{CH}_{4}\right)$, and nitrous oxide $\left(\mathrm{N}_{2} \mathrm{O}\right)$ due to their extensive land area (Schimel, Parton, Kittel, Ojima, \& Cole, 1990; Ojima, Dirks, Glenn, Owensby, \& Scurlock, 1993; Conant, Paustian, \& Elliot, 2001), and low-input management practices (Derner \& Schuman, 2007). Interactions of climate, vegetation and management affect ecosystem responses such as the rate and amount of soil carbon (C) sequestered and the dynamics of individual C pools (Derner, Boutton, \& Briske, 2006; Derner \& Schuman, 2007; Ingram et al., 2008; Follett \& Reed, 2010; Liebig, Gross, Kronberg, Phillips, \& Hanson, 2010; Morgan et al., 2010; Derner \& Jin, 2012).

Ecosystem consequences such as the size of soil $\mathrm{C}$ pools following shrub management in western U.S. rangelands, especially those dominated by Wyoming big sagebrush (Artemisia tridentata Nutt. ssp. wyomingensis Beetle \& Young) in low rainfall areas $(<350 \mathrm{~mm})$, remains a major knowledge gap (Derner \& Schuman, 2007; Morgan et al., 2010; Derner \& Jin, 2012). Despite an extensive history of shrub treatments on these rangelands (Scifres, 1980; Vallentine, 1989), the focus has been on improving forage production (Archer et al., 2011) rather than soil biogeochemical responses. For example, following shrub management in Wyoming big sagebrush communities, increases of $300-500 \%$ in forage production have been observed (Hyder \& Sneva, 1956; McDaniel, Torell, \& Ochoa, 2005), with positive responses occurring for decades (McDaniel et al., 2005). To maintain positive responses in Wyoming big sagebrush communities, subsequent shrub management efforts would need to occur about every 20-30 years (Torell, McDaniel, \& Ochoa, 2005).

Soil $\mathrm{C}$ responses to shrub management has relevance to ecosystem $\mathrm{C}$ balance as soils contain the majority of the 
$\mathrm{C}$ in rangelands, including shrublands (Beier et al., 2009; Pinno \& Wilson, 2011). Total soil C (organic plus inorganic C) in rangeland soils to a 1-m depth ranges from 90 to $266 \mathrm{Mg} \mathrm{C}^{-1}{ }^{-1}$ (Guo, Amundson, Gong, \& Yu, 2006). Total ecosystem $C$ is greater for shrublands compared to grasslands, due to more aboveground biomass $C$ (Pinno \& Wilson, 2011; Qiu et al., 2012). The main factor controlling the fate of soil organic matter (which contains about $57 \%$ soil organic carbon, SOC, by weight), in rangelands is the effect of management on vegetation composition (Derner \& Schuman, 2007). Rangelands tend to be C sinks (Schlesinger, 1997; United States Department of Agriculture, 2008), with SOC sequestration rates of 0.1 to $0.5 \mathrm{Mg} \mathrm{C}^{-1} \mathrm{yr}^{-1}$ (Schuman, Reeder, Manley, Hart, \& Manley, 1999; Derner \& Schuman, 2007; Morgan et al., 2010; Liebig et al., 2010; Derner \& Jin, 2012).

Shrub management treatments include mechanical methods and herbicide applications. These treatments were commonly applied indiscriminately for widespread eradication of shrubs in the 1940s and 1950s; more contemporary efforts have selectively targeted control efforts on the landscape with an emphasis on altering shrub density and cover to provide a wider range of ecosystem services (Archer et al., 2011). For example, Bastian, Peck, Smith and Jacobs (2012) determined that at canopy cover levels of $8-24 \%$ it is economically justified to alter the density and cover of Wyoming big sagebrush. Modifying the structural characteristics of Wyoming big sagebrush plants through mowing or use of selective herbicides can improve wildlife habitat, create fuel breaks for fire suppression, and increase herbaceous production by increasing resource (e.g., soil water) availability and reducing the ability of Wyoming big sagebrush to compete with understory vegetation (Pechanec, Plummer, Robertson, \& Hull, 1965; Davies, Bates, Johnson, \& Nafus, 2009; Davies, Bates, \& Nafus, 2011). Mowing reduces structural characteristics of Wyoming big sagebrush for up to 20 years (Davies et al., 2009) and can increase annual forbs, but also increases the risk of exotic annual grasses invading and dominating the herbaceous community (Davies et al., 2011). Herbicides, including tebuthiuron (trade name SPIKE 20P, Dow Elanco Co., Indianapolis, IN, USA) alter vegetation structure by selectively thinning Wyoming big sagebrush when applied at low rates (Olson \& Whitson, 2002; Blumenthal, Norton, Derner, \& Reeder, 2006).

Objectives of this study were to determine the plant and soil consequences of shrub management treatments in a Wyoming big sagebrush-dominated rangeland ecosystem. We focus on aboveground vegetation (cover, density) and belowground SOC responses. We hypothesized that mowing Wyoming big sagebrush would increase cover of perennial grasses, without negatively influencing the stand density of Wyoming big sagebrush or decreasing SOC. In contrast, we hypothesized that the selective thinning of Wyoming big sagebrush using a low application rate of tebuthiuron would elicit increased SOC in near surface depths through reduction of densities of Wyoming big sagebrush and the resulting decay of aboveground stored $\mathrm{C}$ in biomass and belowground root $\mathrm{C}$ of these plants.

\section{Method}

\subsection{Site Description}

Research plots were located on Bureau of Land Management allotments north (Seedskadee) and northeast (Cow Hollow) of Kemmerer, WY, with a similar, extensive history of livestock grazing at moderate stocking rates. Mean annual precipitation at Kemmerer is $277 \mathrm{~mm}$, and mean average temperature is $3.6{ }^{\circ} \mathrm{C}$ (http://www.usclimatedata.com/climate.php?location=USWY0095). Two ecological sites were studied: 1) Sandy GR (R034AY150WY) at the Seedskadee allotment (SES) and 2) Loamy GR (R034AY122WY) at the Cow Hollow allotment (LES) (for information on ecological sites visit https://esis.sc.egov.usda.gov). Both sites are in the 178 to $229 \mathrm{~mm}$ precipitation zone, Green River and Great Divide Basins. The SES has fine sandy loam or sandy loam surface soils with loamy subsurface soils (e.g., loamy-skeletal, mixed, superactive, frigid typichaplocaclids). The LES has thin, coarse loamy surface soils with loamy subsurface soils (e.g., fine-loamy, mixed, superactive, frigid typichaplargids). Vegetation in both ecological sites is dominated by Wyoming big sagebrush with an understory of perennial cool-season grasses. Total annual production for plant communities in high ecological condition state of SES is $616 \mathrm{~kg} \mathrm{ha}^{-1}$ (392 kg ha-1 in unfavorable years to $840 \mathrm{~kg} \mathrm{ha}^{-1}$ in above-average years). For LES, the value is $560 \mathrm{~kg} \mathrm{ha}^{-1}$ (336 kg ha ${ }^{-1}$ in unfavorable years to $784 \mathrm{~kg} \mathrm{ha}^{-1}$ in above-average years) (http://esis.sc.egov.usda.gov/). As Wyoming big sagebrush becomes more dominant in plant communities for both ecological sites, total annual production decreases by $35-70 \%$.

Using paired sets of management treatments with pseudo-replication is commonplace for studies that are evaluating past, long-term effects of land management treatments on ecosystem consequences, especially soil C (reviewed in Derner \& Schuman, 2007). At each ecological site we evaluated paired sets of shrub management treatments.

For the SES, a mowing treatment of $10 \mathrm{~cm}$ (4 ha area mowed in 2002 using a tractor-mounted rotary mower) 
was used in both a bunchgrass and rhizomatous grass understory to pair with adjacent control locations dominated by Wyoming big sagebrush. For the bunchgrass understory, dominant grasses were needle and thread [Hesperostipa comata (Trin. \& Rupr.) Barkworth] and Indian ricegrass [Achnatherum hymenoides (Roem. \& Schult.) Barkworth].For the rhizomatous wheatgrass understory, thickspike wheatgrass [Elymus lanceolatus (Scribn. \& J. G. Sm) Gould] was the dominant grass.

For the LES, shrub management treatments of mowing to $10 \mathrm{~cm}$ (4 ha area mowed in 1997 using a tractor-mounted rotary mower) and herbicide application (1997 aerial application of tebuthiuron at a rate of 0.34 $\mathrm{kg}$ a.i. ha ${ }^{-1}$, applied to $65 \mathrm{ha}$ ) were paired to adjacent control locations dominated by Wyoming big sagebrush. All locations in the LES had an understory of native cool-season rhizomatous wheatgrasses (e.g., western wheatgrass [Pascopyrum smithii (Rydb.) Á. Löve]).

\subsection{Soil and Vegetation Sampling}

Soil samples $(\mathrm{n}=40)$ were collected in May 2009 from two randomly located $50 \mathrm{~m}$ transects for each shrub management treatment. Five locations along each transect $(0,10,20,30$ and $40 \mathrm{~m})$ were sampled using a tractor mounted Giddings hydraulic soil sampler. This same soil sampling design has been used in prior studies in semiarid rangelands (e.g., Schuman et al., 1999; Ingram et al., 2008). Shrubs can potentially produce "resource islands" or "islands of fertility" (Charley \& West, 1977; Smith, Halvorson, \& Bolton, 1994). Therefore, four soil cores (4 cm inside diameter) to $30 \mathrm{~cm}$ depth were taken at each sampling location with stratification of two cores each at the dripline of the nearest Wyoming big sagebrush plant and two additional cores collected either between Wyoming big sagebrush plants (bunchgrass or rhizomatous grass in the shrub treatments) or from bare ground in the controls. Because SOC is concentrated in the upper soil depths (Weaver, Hougen, \& Weldon, 1935; Gill, Burke, Milchunas, \& Lauenroth, 1999; Derner et al., 2006), and dry soils precluded deeper sampling, we limited sampling to $30 \mathrm{~cm}$. At the 10 and $30 \mathrm{~m}$ locations along each transect, two additional soil cores were taken for determinations of soil bulk density to convert concentrations of soil nitrogen $(\mathrm{N})$ and $\mathrm{C}$ to mass. Soils were separated into $0-5 \mathrm{~cm}, 5-15 \mathrm{~cm}$, and $15-30 \mathrm{~cm}$ increments, with roots removed by hand using a 2-mm sieve prior to grinding of soils for chemical analyses. Soils were analyzed for total $\mathrm{C}$ and $\mathrm{N}$ using an Elementar vario Macro $\mathrm{C} / \mathrm{N}$ analyzer (Elementar Americas, Inc., Mt. Laurel, NJ, USA) and for inorganic $\mathrm{C}$ using the modified pressure-transducer technique (Sherrod, Dunn, Peterson, \& Kolberg, 2002). The difference between total C and inorganic $\mathrm{C}$ was SOC. Concentrations of $\mathrm{C}$ and $\mathrm{N}$ were multiplied by bulk density values to obtain pools of $\mathrm{C}$ and N. Soil particle size distribution was determined by the hydrometer method (Gee \& Bauder, 1986) and soil $\mathrm{pH}$ was measured in a 1:1 suspension mixture of soil:distilled water using a $\mathrm{pH}$ electrode. Soil $\mathrm{pH}$ and clay content for these ecological sites are presented in Table 1.

Table 1. Mean ( $\pm 1 \mathrm{SE})$ soil $\mathrm{pH}$ and \% clay for the Sandy GR Ecological Site (SES) and the Loamy GR Ecological Site (LES)

\begin{tabular}{cccc}
\hline Ecological Site & Depth $(\mathrm{cm})$ & Soil pH & \% Clay \\
\hline SES & $0-5$ & $7.8(0.1)$ & $19(2)$ \\
& $5-15$ & $7.9(0.1)$ & $25(1)$ \\
& $15-30$ & $8.1(0.1)$ & $29(2)$ \\
\multirow{2}{*}{ LES } & $0-5$ & $7.8(0.1)$ & $18(2)$ \\
& $5-15$ & $7.9(0.1)$ & $24(1)$ \\
& $15-30$ & $8.3(0.1)$ & $31(2)$ \\
\hline
\end{tabular}

To determine vegetation responses, we established six randomly located $50 \mathrm{~m}$ transects for each treatment in August 2009 adjacent to where soil sampling occurred in May 2009. We determined percent cover, frequency (total number of intercepts) and average intercept lengths of perennial grasses (individual species not identified), Wyoming big sagebrush and bare ground using line intercept methods. We also determined density (number of both live and dead plants) and height of Wyoming big sagebrush plants using one 1-m wide belt on each of the $50 \mathrm{~m}$ transects. 


\subsection{Statistical Analyses}

Data were analyzed separately by ecological site because shrub management treatments were conducted at different times for each site. For each ecological site, a one-way Analysis of Variance (ANOVA) was used to test the main effect of shrub treatment for vegetation and soil data in each paired plot comparison separately using PROC GLM (SAS Institute, 2006). For soils data, comparisons were conducted at each depth and for the 0-30 cumulative depth. Means were separated using the least squares PDIFF option when the F test of the main effect was significant at $\mathrm{P}<0.05$.

\section{Results}

\subsection{Sandy Ecological Site (SES)}

\subsubsection{Vegetation Responses}

Mowing in 2002 did not influence live Wyoming big sagebrush plant density, but the density of dead Wyoming big sagebrush plants was three- to four-fold greater, and heights of live plants were shorter (Figure 1A). Mowing also increased the intercept frequency of perennial grasses and bare ground, but not for Wyoming big sagebrush (Figure 2A). The intercept lengths of Wyoming big sagebrush, as well as for bare ground, were shorter with mowing (Figure 2B). Significant increases in percent cover of perennial grasses and decreases in percent cover of Wyoming big sagebrush were observed, whereas percent bare ground was unaffected by mowing (Figure 2C).

\subsubsection{Soil Responses}

Soil $\mathrm{C}$ and $\mathrm{N}$ did not differ between samples collected at the dripline and between the Wyoming big sagebrush plants $(\mathrm{P}>0.05)$, so the dripline and interspace data values were pooled for analyses. Mowing increased soil $\mathrm{N}$ in the $5-15 \mathrm{~cm}, 15-30 \mathrm{~cm}$ and for the combined $0-30 \mathrm{~cm}$ depth increments in the bunchgrass community compared to the control site (Figure 3A). Conversely, no differences were observed between the rhizomatous community and control site for soil N. Soil organic $\mathrm{C}$ was similar at all depths across mowing treatments and control (Figure 3B). 


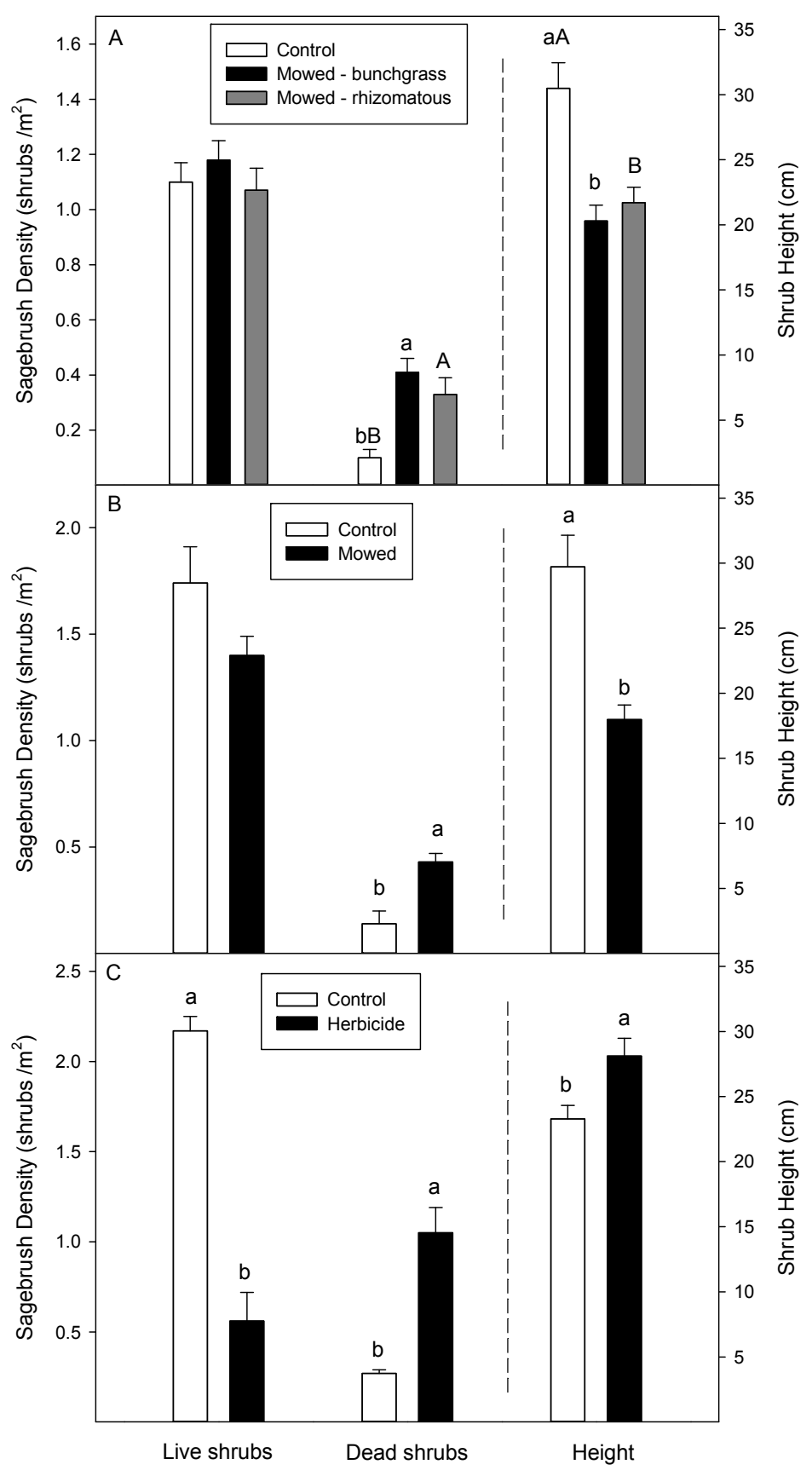

Figure 1. Sagebrush density (plants $\mathrm{m}^{-2}$ ) and height $(\mathrm{cm})$ responses at the (A) Sandy GR Ecological Site (SES) to mowing of sagebrush in 2002, (B) Loamy GR Ecological Site (LES) to mowing of sagebrush in 1997, and (C) LES to herbicide application (tebuthiuron) to sagebrush in 1997. Vegetation data collected in August 2009. Lowercase letters indicate significant $(\mathrm{P}<0.05)$ differences between the mowed-bunchgrass treatment and the control, and uppercase letters indicate significant $(\mathrm{P}<0.05)$ differences between the mowed-rhizomatous treatment and the control 


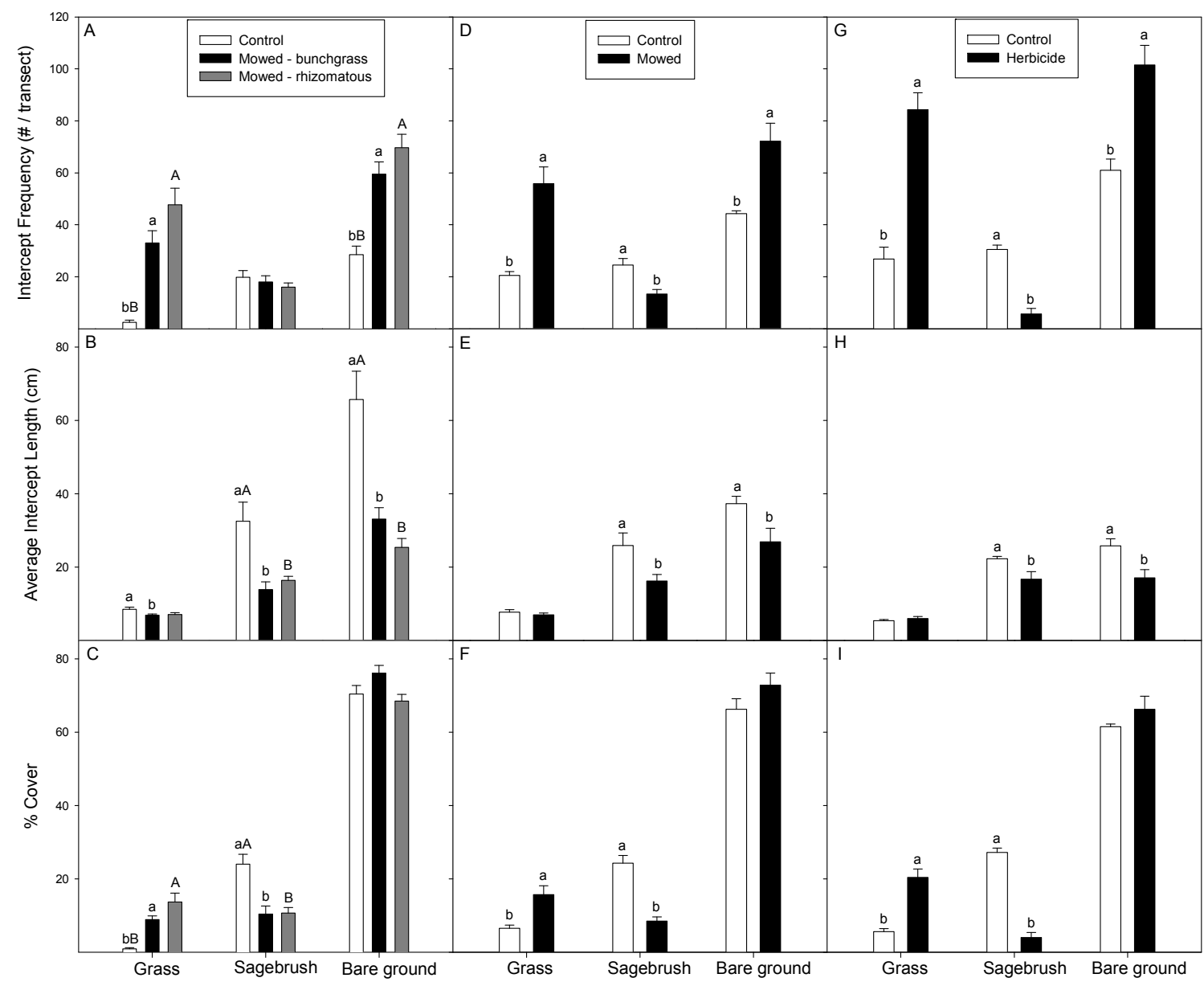

Figure 2. Vegetation responses (intercept frequency, average intercept length, and canopy cover) at the (A-C) Sandy GR Ecological Site (SES) to mowing of sagebrush in 2002, (D-F) Loamy GR Ecological Site (LES) to mowing of sagebrush in 1997, and (G-I) LES to herbicide application (tebuthiuron) to sagebrush in 1997.

Vegetation data collected in August 2009. Lowercase letters indicate significant $(\mathrm{P}<0.05)$ differences between the mowed-bunchgrass treatment and the control, and uppercase letters indicate significant $(\mathrm{P}<0.05)$ differences between the mowed-rhizomatous treatment and the control 


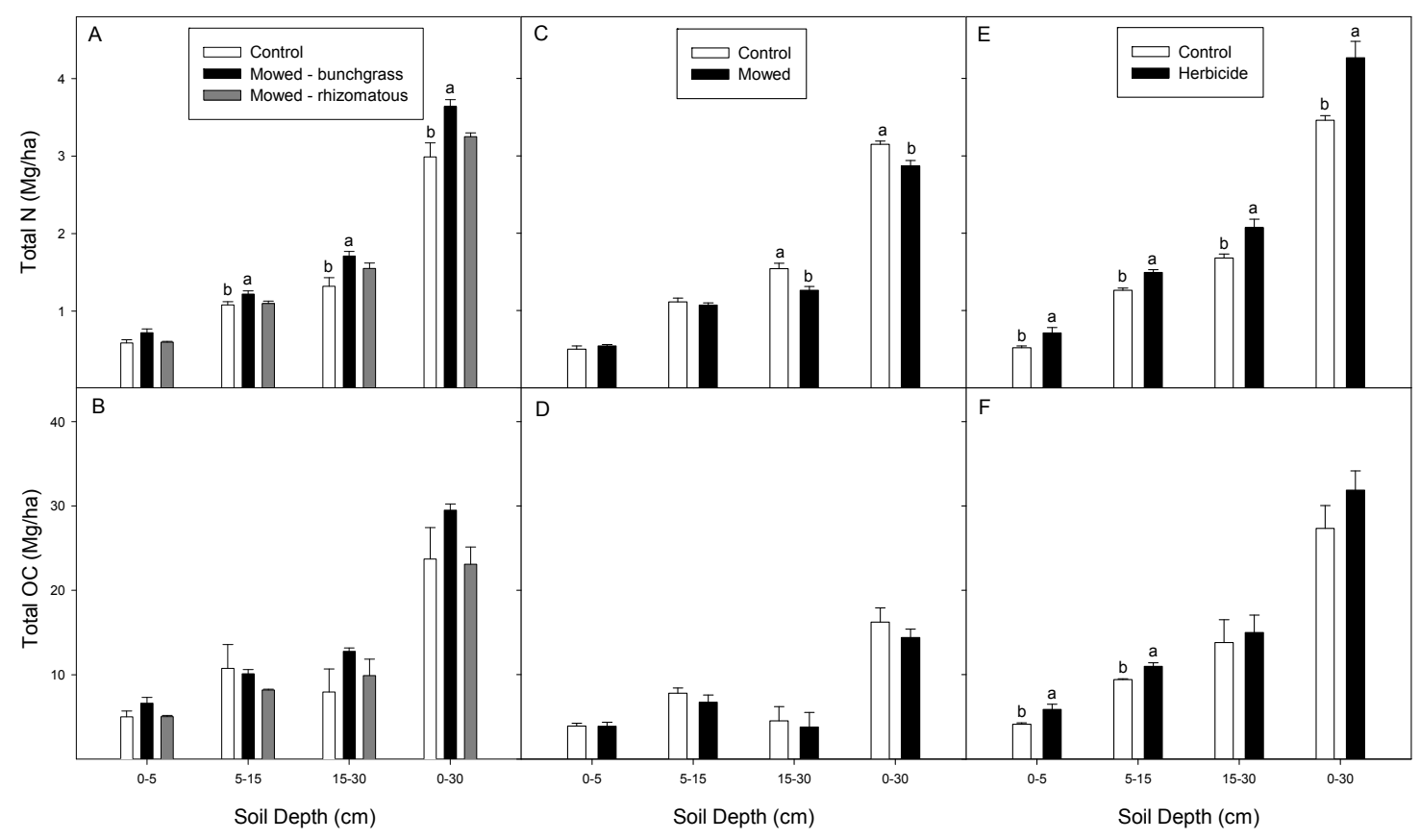

Figure 3. Soil nitrogen (N) and organic carbon (OC) responses at the (A-B) Sandy GR Ecological Site (SES) to mowing of sagebrush in 2002, (C-D) Loamy GR Ecological Site (LES) to mowing of sagebrush in 1997, and

(E-F) LES to herbicide application (tebuthiuron) to sagebrush in 1997. Soil data collected in May 2009.

Lowercase letters indicate significant $(\mathrm{P}<0.05)$ differences between the mowed-bunchgrass treatment and the control, and uppercase letters indicate significant $(\mathrm{P}<0.05)$ differences between the mowed-rhizomatous treatment and the control

\subsection{Loamy Ecological Site (LES)}

\subsubsection{Vegetation Responses}

Mowing elicited similar findings within the LES as observed for the SES. Mowing in 1997 did not influence density of live Wyoming big sagebrush plants, but the density of dead plants was about three-fold greater, and heights of live plants were also shorter (Figure 1B). Mowing substantially increased the intercept frequency of perennial grasses and bare ground, and reduced the frequency of Wyoming big sagebrush (Figure 2D). Mowing resulted in shorter intercept lengths of Wyoming big sagebrush as well as bare ground (Figure 2E). Percent cover of perennial grasses increased with mowing, whereas percent cover of Wyoming big sagebrush decreased; and percent bare ground was unaffected by mowing (Figure 2F).

The herbicide shrub treatment in 1997 had similar effects on vegetation responses as did mowing, with the exceptions of reducing density of live Wyoming big sagebrush plants and increasing height of the remaining live plants. Density of live Wyoming big sagebrush plants was reduced by four-fold, whereas the density of dead plants was about four-fold greater, and the heights of live plants were greater with the herbicide treatment (Figure 1C). Herbicide application, like mowing, substantially increased the intercept frequency of perennial grasses and bare ground, and reduced the intercept frequency of Wyoming big sagebrush (Figure 2G). Shorter intercept lengths of Wyoming big sagebrush as well as bare ground were also determined (Figure 2H). Percent cover of perennial grasses increased, percent cover of Wyoming big sagebrush decreased, and percent bare ground were unaffected by the herbicide treatment (Figure 2I).

\subsubsection{Soil Responses}

Consistent with the SES, soil $\mathrm{C}$ and $\mathrm{N}$ did not differ between samples collected at the dripline and between the Wyoming big sagebrush plants $(\mathrm{P}>0.05)$, so these values were pooled for analyses. Mowing in 1997 did not influence soil $\mathrm{N}$ in the two upper soil depths (Figure 3C) nor did it influence SOC across all three soil depths (Figure 3D). In contrast, herbicide application in 1997 consistently increased soil $\mathrm{N}$ at all three soil depths 
(Figure 3E) and SOC was greater in both the 0-5 $\mathrm{cm}(43 \%)$ and 5-15 $\mathrm{cm}(17 \%)$ soil depths (Figure 3F).

\section{Discussion}

Plant consequences of shrub management treatments (mowing and aerial herbicide application) in Wyoming big sagebrush-dominated rangelands of southwestern Wyoming on two different ecological sites were consistent for responses to mowing for the SES and LES through 1) no effects on live, but three- to four-fold increases in dead, Wyoming big sagebrush plant densities, 2) reduced height and cover of Wyoming big sagebrush, 3) increased cover of perennial grasses, and 4) no effects on bare ground. Vegetation responses to the herbicide application were similar to mowing with the notable exception of substantially lower densities, but taller live Wyoming big sagebrush plants. Soil responses, in contrast, were not affected by mowing for either SES or LES. Increased SOC was observed with herbicide application in the LES for both the upper two soil depths $(0-5 \mathrm{~cm}$ and $5-15 \mathrm{~cm})$.

Though we did not directly quantify pools of $\mathrm{C}$ in decaying woody tissues, using developed relationships from Rittenhouse and Sneva (1977) for predicting aboveground biomass production of plants from height $(25 \mathrm{~cm}$ from Figure 1C) and canopy width (i.e., intercept length from Figure $2 \mathrm{H}, 20 \mathrm{~cm}$ ), estimated annual aboveground biomass production (photosynthetic and woody total) for Wyoming big sagebrush plants at the LES control area would be $19.8 \mathrm{~g} \mathrm{plant}^{-1}$. Multiplying this by the difference between live and dead plant densities $\left(1.5\right.$ plants $\mathrm{m}^{-2}$, Figure 1C), we can estimate that the lost pool of annual aboveground $\mathrm{C}$ associated with plants selectively thinned by the herbicide in 1997 would be $0.13 \mathrm{Mg} \mathrm{C}^{-1} \mathrm{yr}^{-1}\left(15,000\right.$ plants ha $^{-1} \times 19.8 \mathrm{~g} \mathrm{plant}^{-1} \times 44 \%$ carbon in biomass). Moreover, using aboveground $\left(563 \mathrm{~g} \mathrm{plant}^{-1}\right)$ and root $\left(225 \mathrm{~g} \mathrm{plant}^{-1}\right)$ biomass values for individual Wyoming big sagebrush plants (Sturges \& Trlica, 1978), we estimate that a total of $5.20 \mathrm{Mg} \mathrm{C} \mathrm{ha}^{-1}(15,000$ plants ha ${ }^{-1} \times 788$ g plant $^{-1} \times 44 \%$ carbon in biomass) would be classified as $\mathrm{C}$ associated with dead woody plant tissue as a result of the herbicide application. Approximately $1.50 \mathrm{Mg} \mathrm{C}^{-1}$ would be from roots and about half of this would be located in upper $30 \mathrm{~cm}$ of the soil profile given the root biomass distribution of Wyoming big sagebrush (Sturges \& Trlica, 1978). Twelve years following the herbicide treatment, we found an additional 1.76 and $1.58 \mathrm{Mg} \mathrm{C} \mathrm{ha}^{-1}$ of SOC in the 0-5 and 5-15 cm soil depths, respectively, in the plots that had the herbicide treatment compared to control sites. These values correspond to annual soil $\mathrm{C}$ sequestration rates of 0.16 and $0.14 \mathrm{Mg} \mathrm{C} \mathrm{ha}{ }^{-1} \mathrm{yr}^{-1}$ for the $0-5$ and 5-15 cm soil depths, respectively. Similar rates of SOC sequestration have been reported for semiarid (340 $\mathrm{mm}$ mean annual precipitation) shortgrass prairie in Colorado with grazing (Derner \& Schuman, 2007).

Despite the limited research findings and highly variable data on soil C responses to shrub management practices, inferences can be drawn from a larger set of studies evaluating shrub-induced changes to SOC through encroachment of rangelands by shrubs. Experiments have demonstrated positive impacts to SOC due to shrub encroachment (Archer et al., 2011). When increases in SOC do occur, these are often observed in the upper soil profile $(0-20 \mathrm{~cm}$, Boutton, Liao, Filley, \& Archer, 2009) with accumulation rates ranging from 80 to $300 \mathrm{~kg} \mathrm{C}$ $\mathrm{ha}^{-1} \mathrm{yr}^{-1}$ (Wheeler, Archer, Asner, \& McMurtry, 2007), and associated increases in soil N occur (Wheeler et al., 2007). Conversely, complete removal of individual shrubs that have encroached in hot desert rangelands can substantially $(67-106 \%)$ reduce SOC and $\mathrm{N}$ in upper $(0-10 \mathrm{~cm})$ soil depths (McClaran, Moore-Kucera, Martens, Haren, \& Marsh, 2008). This loss of SOC and N occurs over a period of about 10-15 years (Klemmedson \& Tiedemann, 1986; Tiedemann \& Klemmedson, 1986, 2004).

There have been numerous attempts over the years to eradicate shrubs and target increased forage production from herbaceous plants through shrub management practices on western rangelands (Archer et al., 2011). Contemporary applications of shrub management, however, are implemented to address multiple ecosystem goods and services (Follett \& Reed, 2010), including promotion of suitable wildlife habitat (Archer et al., 2011). This is often the case in Wyoming big sagebrush rangeland systems where the greater sage-grouse (Centrocercus urophasianus) is a focal grassland bird species. Greater sage-grouse are highly dependent on a heterogeneous mosaic of shrub densities, cover and heights throughout its life stages (Connelly, Schroeder, Sands, \& Braun, 2000; Crawford et al., 2004; Hagen, Connelly, \& Schroeder, 2007). Davies, Bates and Miller (2006) reported that $90 \%$ of the Wyoming big sagebrush cover values were between $6 \%$ and $20 \%$ in Wyoming, and in the meta-analysis by Hagen et al. (2007) shrub cover values of 7-29\% were observed for nesting and brood-rearing habitats of greater sage-grouse. Our results are consistent across two ecological sites (SES and LES) with mowing reducing sagebrush height and cover while concurrently increasing cover of perennial grasses and not detrimentally impacting bare ground. Therefore, mowing is a shrub management tool that can be targeted for use on landscapes to alter Wyoming big sagebrush structure and increase perennial grasses while not detrimentally impacting percent bare ground. Caution is needed in using mowing as a management tool, however, as it may negatively impact winter habitat for wildlife (Davies et al., 2009) and can increase risk of invasion by exotic annual grasses (Davies et al., 2011). To lessen these deleterious impacts, mowing can be targeted on areas that 
have an understory of perennial grasses which can respond following the mowing event and be strategically incorporated on the landscape to enhance a mosaic of Wyoming big sagebrush plant communities (Archer et al., 2011). Likewise, targeted use of selective herbicides can elicit similar vegetation changes as mowing, with lower densities of live Wyoming big sagebrush plants and taller remaining live plants. Greater sage-grouse had higher brood use on plots treated with herbicide than control plots in Utah due to more herbaceous cover (Dalhlgren, Chi, \& Messmer, 2006). Incorporation of herbicide shrub management treatments on the landscape can enhance heterogeneity of vegetation structure in sagebrush steppe ecosystems.

Plant consequences of mowing Wyoming big sagebrush in both SES and LES were positive for modifying vegetation structure and composition, but utilization of this shrub management treatment on the landscape for increased soil C is not justified given our findings of no changes in SOC. Whereas plant consequences of aerial application of the selective herbicide tebuthiuron were also positive for modifying vegetation structure and composition, SOC and soil N pools were enhanced as well as decaying woody tissues (both above- and below-ground) with this shrub management treatment. Sequestration rates of SOC for Wyoming big sagebrush communities treated with the selective herbicide provide much needed scientific information regarding soil $\mathrm{C}$ responses to land management in western U.S. rangelands, especially those with a Wyoming big sagebrush (Artemisia tridentata Nutt. ssp. wyomingensis Beetle \& Young) component and in lower rainfall areas $(<350$ mm) (Derner \& Schuman, 2007; Morgan et al., 2010; Derner \& Jin, 2012). These findings provide evidence that sagebrush-dominated semiarid rangelands have the capacity to increase soil $\mathrm{C}$ following vegetation manipulation when herbicides are used to selectively thin Wyoming big sagebrush plants. Therefore, land managers looking at shrub management practices to increase soil $\mathrm{C}$ and possibly participate in $\mathrm{C}$ offset programs (Ritten, Bastian, \& Rashford, 2012) could consider herbicide treatments as a shrub management practice.

\section{Acknowledgments}

Marion Mahaffey, Bureau of Land Management, Kemmerer Field Office, provided information on shrub treatments and identification of field sampling locations. Karen Clause, Natural Resource Conservation Service, determined ecological sites at the field sampling locations. We appreciate the efforts of Rich Olson, Mary Ashby, Matt Mortenson, and Jeff Thomas in data collection. Alix Hakala conducted the soil $\mathrm{C}$ and $\mathrm{N}$ analyses, and Matt Mortenson conducted the statistical analyses and prepared figures and tables. This publication is based upon work supported by the Agricultural Research Service under the Greenhouse gas Reduction through Agricultural Carbon Enhancement network (GRACEnet) Project. This research was partially funded by a grant through the Wyoming State Department of Agriculture.

\section{References}

Archer, S. R., Davies, W., Fulbright, T. E., McDaniel, K. C., Wilcox, B. P., \& Predick, K. I. (2011). Brush management as a rangeland conservation strategy: A critical evaluation. In D. D. Briske (Ed.), Conservation Benefits of Rangeland Practices: Assessment, Recommendations, and Knowledge Gaps (pp. 105-170). USDA, NRCS. Retrieved http://www.nrcs.usda.gov/wps/portal/nrcs/detail/national/technical/nra/ceap/?\&cid=stelprdb1045811

Bastian, C. T., Peck, D. E., Smith, M. A., \& Jacobs, J. J. (2012). Sagebrush control: at what canopy cover is it economically feasible? Rangeland Ecology and Management, 64, 351-361. http://dx.doi.org/10.2111/REM-D-11-00036.1

Beier, C., Emmett, B. A., Tietema, A., Schmidt, I. K., Penũeles, J., Láng, E. K., ... Spano, D. (2009). Carbon and nitrogen balances for six shrublands across Europe. Global Biogeochemical Cycles, 23, GB4008. http://dx.doi.org/10.1029/2008GB003381

Blumenthal, D., Norton, U., Derner, J. D., \& Reeder, J. D. (2006). Long-term effects of tebuthiuron on $\begin{array}{llll}\text { Bromustectorum. Western North American } & \text { Naturalist, 66, } 425 .\end{array}$ http://dx.doi.org/10.3398/1527-0904(2006)66[420:LEOTOB]2.0.CO;2

Boutton, T., Liao, J., Filley, T., \& Archer, S. (2009). Belowground carbon storage and dynamics following woody plant encroachment in a subtropical savanna. In R. Lal \& R. Follett (Eds.), Soil carbon sequestration and the greenhouse effect (pp. 181-205). WI: Soil Science Society of America.

Charley, J. L., \& West, N. E. (1977). Micro-patterns of nitrogen mineralization activity in soils of some shrub dominated semi-desert ecosystems of Utah. Soil Biology and Biochemistry, 9, 357-365. http://dx.doi.org/10.1016/0038-0717(77)90010-4

Conant. R. T., Paustian, K., \& Elliot, E. T. (2001). Grassland management and conversion into grassland: Effects $\begin{array}{lllll}\text { on soil } & \text { Ecological }\end{array}$ 
http://dx.doi.org/10.1890/1051-0761(2001)011[0343:GMACIG]2.0.CO;2

Connelly, J. W., Schroeder, M. A., Sands, A. R., \& Braun, C. E. (2000). Guidelines to manage sagegrouse populations and their habitats. Wildlife Society Bulletin, 28, 967-985.

Crawford, J. A., Olson, R. A., West, N. E., Mosely, J. C., Schroeder, M. A., Whitson, T. D., ... Boyd, C. S. (2004). Ecology and management of sage-grouse and sage-grouse habitat. Rangeland Ecology and Management, 57, 2-19. http://dx.doi.org/10.2111/1551-5028(2004)057[0002:EAMOSA]2.0.CO;2

Dahlgren, D. K, Chi, R., \& Messmer, T. D. (2006). Greater sage-grouse response to sagebrush management in Utah. Wildlife Society Bulletin, 34, 975-985.

Davies, K. W., Bates, J. D., \& Miller, R. F. (2006). Vegetation characteristics across part of the Wyoming big sagebrush alliance. Rangeland Ecology and Management, 59, 567-575. http://dx.doi.org/10.2111/06-004R2.1

Davies, K. W., Bates, J. D., Johnson, D. D., \& Nafus, A. M. (2009). Influence of mowing Artemisia tridentata ssp. wyomingensis on winter habitat for wildlife. Environmental Management, 44, 84-92. http://dx.doi.org/10.1007/s00267-008-9258-4

Davies, K. W., Bates, J. D., \& Nafus, A. M. (2011). Are there benefits to mowing Wyoming big sagebrush plant communities? An evaluation in southeastern Oregon. Environmental Management, 48, 539-546. http://dx.doi.org/10.1007/s00267-011-9715-3

Derner, J. D., Boutton, T. W., \& Briske, D. D. (2006). Grazing and ecosystem carbon storage in the North American Great Plains. Plant and Soil, 280, 77-90. http://dx.doi.org/10.1007/s11104-005-2554-3

Derner, J. D., \& Jin, V. L. (2012). Soil carbon dynamics and rangeland management. In M. A. Liebig, A. J. Franzluebbers \& R. F. Follett (Eds.), Managing agricultural greenhouse gases (pp. 79-92). Amsterdam: Elsevier.

Derner, J. D., \& Schuman, G. E. (2007). Carbon sequestration and rangelands: A synthesis of land management and precipitation effects. Journal of Soil and Water Conservation, 62, 77-85.

Follett, R. F., \& Reed, D. (2010). Soil carbon sequestration in grazing lands: Societal benefits and policy implications. Rangeland Ecology and Management, 63, 4-15. http://dx.doi.org/10.2111/08-225.1

Gee, G. W., \& Bauder, J. W. (1986). Particle size analysis. In Methods of soil analysis, part 1 (pp. 383-411), Agronomy Monograph 9. Madison, WI: American Society of Agronomy.

Gill, R. A., Burke, I. C., Milchunas, D. G., \& Lauenroth, W. K. (1999). Relationship between root biomass and soil organic matter pools in the shortgrass steppe of eastern Colorado: Implications for decomposition through a soil profile. Ecosystems, 2, 226-236. http://dx.doi.org/10.1007/s100219900070

Guo, Y., Amundson, R., Gong, P., \& Yu, Q. (2006). Quantity and spatial variability of soil carbon in the conterminous United States. Soil Science Society of America Journal, 70, 590-600. http://dx.doi.org/10.2136/sssaj2005.0162

Hagen, C. A., Connelly, J. W., \& Schroeder, M. A. (2007). A meta-analysis of greater sage grouse Centrocercusurophasianus nesting and brood-rearing habitats. Wildlife Biology, 13, 42-50. http://dx.doi.org/10.2981/0909-6396(2007)13[42:AMOGSC]2.0.CO;2

Hyder, D. N., \& Sneva, F. A. (1956). Herbage response to sagebrush spraying. Journal of Range Management, 9 , 34-38. http://dx.doi.org/10.2307/3894650

Ingram, L. J., Stahl, P. D., Schuman, G. E., Buyer, J. S., Vance, G. F., Ganjegunte, G. K., ... Derner, J. D. (2008). Grazing impacts on soil carbon and microbial communities in a mixed-grass ecosystem. Soil Science Society of America Journal, 72, 939-948. http://dx.doi.org/10.2136/sssaj2007.0038

Klemmedson, J. O., \& Tiedemann, A. R. (1986). Long-term effects of mesquite removal on soil characteristics: II. Nutrient availability. Soil Science Society of America Journal, 50, 476-480.

Liebig, M. A., Gross, J. R., Kronberg, S. L., Phillips, R. L., \& Hanson, J. D. (2010). Grazing management contributions to net global warming potential: a long-term evaluation in the northern Great Plains. Journal of Environmental Quality, 39, 799-809. http://dx.doi.org/10.2134/jeq2009.0272

McClaran, M. P., Moore-Kucera, J., Martens, D. A., Haren, J. V., \& Marsh, S. E. (2008). Soil carbon and nitrogen response to size and death of woody plants in a semi-arid grassland. Geoderma, 145, 60-68. http://dx.doi.org/10.1016/j.geoderma.2008.02.006 
McDaniel, K. C., Torell, L. A., \& Ochoa, C. G. (2005). Wyoming big sagebrush recovery and understory response with tebuthiuron control. Rangeland Ecology and Management, 58, 65-76. $\mathrm{http}: / / \mathrm{dx}$. doi.org/10.2111/1551-5028(2005)58\%3C65:WBSRAU\%3E2.0.CO;2

Morgan, J. A., Follett, R. F., Allen Jr, L. H., Del Grosso, S., Derner, J. D., Dijkstra, F., ... Schoeneberger, M. M. (2010). Carbon sequestration in agricultural lands of the United States. Journal of Soil and Water Conservation, 65, 6A-13A. http://dx.doi.org/10.2489/jswc.65.1.6A

Ojima, D. S., Dirks, B. O., Glenn, E. P., Owensby, C. E., \& Scurlock, J. O. (1993). Assessment of C budget for grasslands and drylands of the world. Water, Air, and Soil Pollution, 70, 95-109. http://dx.doi.org/10.1007/BF01104990

Olson, R. A., \& Whitson, T. D. (2002). Restoring structure in late-successional sagebrush communities by

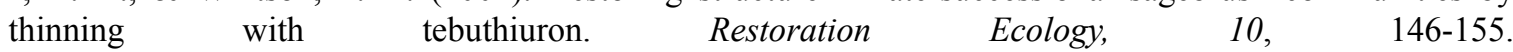
http://dx.doi.org/10.1046/j.1526-100X.2002.10116.x

Pechanec, J. F., Plummer, A. P., Robertson, J. H., \& Hull Jr, A. C. (1965). Sagebrush control on rangelands. USDA Agriculture Handbook 277 (p. 40).

Pinno, B. D., \& Wilson, S. D. (2011). Ecosystem carbon changes with wood encroachment of grassland in the northern Great Plains. Ecoscience, 18, 157-163. http://dx.doi.org/10.2980/18-2-3412

Qiu, L., Wei, W., Zhang, W., Cheng, J., Gale, W., Guo, C., \& Long, T. (2012). Soil organic carbon losses due to land change in a semiarid grassland. Plant and Soil, 355, 299-309. http://dx.doi.org/10.1007/s11104-011-1099-x

Ritten, J. P., Bastian, C. T., \& Rashford, B. S. (2012). Profitability of carbon sequestration in western rangelands of the United States. Rangeland Ecology and Management, 64, 340-350. http://dx.doi.org/10.2111/REM-D-10-00191.1

Rittenhouse, L. R., \& Sneva, F. A. (1977). A technique for estimating big sagebrush production. Journal of Range Management, 30, 68-70. http://dx.doi.org/10.2307/3897341

SAS Institute Inc. (2006). SAS OnlineDoc ${ }^{\circledR}$ 9.1.3. Cary, NC, USA: SAS Institute, Inc.

Schimel, D. S., Parton, W. J., Kittel, T. G., Ojima, D. S., \& Cole, C. V. (1990). Grassland biogeochemistry: links to atmospheric processes. Climate Change, 17, 13-25. http://dx.doi.org/10.1007/BF00148998

Schlesinger, W. H. (1997). Biogeochemistry: Analysis of global change (2nd ed.). San Diego, CA; Academic Press, Inc.

Schuman, G. E., Reeder, J. D., Manley, J. T., Hart, R. H., \& Manley, W. A. (1999). Impact of grazing management on the carbon and nitrogen balance of a mixed-grass rangeland. Ecological Applications, 9, 65-71. http://dx.doi.org/10.1890/1051-0761(1999)009[0065:IOGMOT]2.0.CO;2

Scifres, C. J. (1980). Brush management. College Station, TX; Texas A \& M University Press.

Sherrod, L. A., Dunn, G., Peterson, G. A., \& Kolberg, R. L. (2002). Inorganic carbon analysis by modified pressure-calcimeter method. Soil Science Society of America Journal, 66, 299-305. http://dx.doi.org/10.2136/sssaj2002.0299

Smith, J. L., Halvorson, J. J., \& Bolton Jr., H. (1994). Spatial relationships of soil microbial biomass and C and N mineralization in a semi-arid shrub-steppe ecosystem. Soil Biology and Biochemistry, 26, 1151-1159. http://dx.doi.org/10.1016/0038-0717(94)90137-6

Sturges, D. L., \& Trlica, M. J. (1978). Root weights and carbohydrate reserves of big sagebrush. Ecology, 59, 1282-1285. http://dx.doi.org/10.2307/1938244

Tiedemann, A. R., \& Klemmedson, J. O. (1986). Long-term effects of mesquite removal on soil characteristics: I. Nutrients and bulk density. Soil Science Society of America Journal, 50, 472-475. http://dx.doi.org/10.2136/sssaj1986.03615995005000020044x

Tiedemann, A. R., \& Klemmedson, J. O. (2004). Responses of desert grassland vegetation to mesquite removal and regrowth. Journal of Range Management, 57, 455-465. http://dx.doi.org/10.2307/4003974

Torell, L. A., McDaniel, K. C., \& Ochoa, C. G. (2005). Economics and optimal frequency of Wyoming big sagebrush control with tebuthiuron. Rangeland Ecology and Management, 58, 77-84. http://dx.doi.org/10.2111/1551-5028(2005)58\%3C77:EAOFOW\%3E2.0.CO;2

USDA (United States Department of Agriculture). (2008). U.S. Agriculture and Forestry Greenhouse Gas 
Inventory: 1990-2005. Global Change Program Office, Office of the Chief Economist, USDA Tech Bull No. 1921.

Vallentine, J. R. (1989). Range development and improvements. San Diego, CA; Academic Press, Inc.

Weaver, J. E., Hougen, V. H., \& Weldon, M. D. (1935). Relation of root distribution of organic matter in prairie soil. Botanical Gazette, 96, 389-420.

Wheeler, C. W., Archer, S., Asner, G, \& McMurtry, C. (2007). Climate and edaphic controls on soil carbon-nitrogen responses to woody plant encroachment in desert grassland. Ecological Applications, 17, 1911-1928. http://dx.doi.org/10.1890/06-1580.1

\section{Copyrights}

Copyright for this article is retained by the author(s), with first publication rights granted to the journal.

This is an open-access article distributed under the terms and conditions of the Creative Commons Attribution license (http://creativecommons.org/licenses/by/3.0/). 